\title{
Glycine transport in mouse eggs and preimplantation embryos*
}

\author{
J. G. Hobbs and P. L. Kaye
}

Department of Physiology and Pharmacology, University of Queensland, St Lucia, Queensland 4067, Australia

\begin{abstract}
Summary. In pre-compaction embryos glycine was taken up by the glycine-specific glysystem, which is concentrative, weakly exchangeable and dependent on $\mathrm{Na}^{+}$. After compaction glycine uptake increased, apparently due to the expression of the Atransport system and its reactivity with glycine. Studies of the metabolic fate of carbon from glycine indicated conversion to serine and alanine. These changes are interpreted to show that glycine could provide carbon for intermediary energy metabolism, resulting in $\mathrm{CO}_{2}$, as well as for macromolecular synthesis.
\end{abstract}

\section{Introduction}

The source of amino acids for protein synthesis in the preimplantation mouse embryo is unknown. At least some is assumed to be from turnover of protein, since normal development can occur in vitro in the absence of an exogenous nitrogen source (Caro, Trounson \& Pugh, 1982). Measurements of amino acid levels at several stages of early development (Schultz, Kaye. McKay \& Johnson, 1981) revealed concentrations similar to those of sea urchins (Fry \& Gross, 1970) with the levels of most amino acids increasing during development in vivo. The situation appears to be similar when mouse embryos develop in vitro in the absence of amino acids, but the total amino acid pool is smaller (Sellens, Stein \& Sherman, 1981). Embryos may therefore have access to amino acids in the oviduct and accumulate these by specific transport systems resembling those described in many other tissues (Borland \& Tasca, 1974; Kaye, Schultz, Johnson, Pratt \& Church, 1982).

Generally, these amino acid transport systems have specific reactivities (Christensen, 1979). In particular one system ( $g l y$-system) appears to transport glycine specifically. Glycine is a key metabolite, being a precursor for protein, nucleic acid and energy and is present at very high levels in the mouse egg $(\sim 20 \mathrm{mM})$. Furthermore, during development from egg to blastocyst in vivo the glycine concentration falls by about $90 \%$ (Schultz et al., 1981).

Since the energy and amino acid metabolism of the embryo is not fully understood we have studied the transport of glycine by mouse eggs and embryos.

\section{Materials and Methods}

Mice. Mice (Quackenbush strain) were randomly bred in our own animal house from a starter nucleus obtained from the Department of Veterinary Physiology, University of Sydney, Australia. Stocks of female mice for superovulation were housed in a separate room from breeder pairs and male mice. Lights were on from 06:00 to 18:00 h. 
Superovulation and synchronization. Female mice 6-9 weeks of age were injected intraperitoneally with 10 i.u. PMSG (Folligon: Intervet (Aust) Pty Ltd, Artarmon, New South Wales) followed 44-50 h later by 10 i.u. hCG (Chorulon: Intervet (Aust)). Injections of hCG were usually given between $09: 00$ and 12:00 $\mathrm{h}$ but sometimes between 14:00 and 18:00 h. Immediately after hCG injection females were placed with males, usually 2 females to 1 male in each box, and left until $09: 00 \mathrm{~h}$ the next day when they were inspected for vaginal plugs. Using this regimen we obtained a $70 \%$ mating rate, ovulation of about 30 unfertilized eggs per female and 10-15 blastocysts per female. Age of embryos is indicated as h after hCG.

Egg/embryo collection and manipulations. Eggs or embryos were flushed from the oviduct or uterus using PBS (Dulbecco \& Vogt, 1954) or M2 (Fulton \& Whittingham, 1978) medium both modified to contain 0.33 mM-sodium pyruvate (Sigma Chemical Co., St Louis, MO, U.S.A.), 5.6 mM-glucose and $4 \mathrm{~g}$ bovine serum albumin/l (Sigma Product No. 9647). Both media were prepared with triple glass-distilled tap water and equilibrated with $5 \% \mathrm{CO}_{2}$ in air. Glycine uptake by embryos in both media was similar and embryos collected and manipulated in these media before transfer to modified BMOC-2 medium containing $5.56 \mathrm{mM}$-glucose (Brinster, 1965) developed normally to blastocysts in vitro. Amino acid analysis of the bovine serum albumin revealed no significant contamination by any amino acids.

Radioactive media were prepared by the addition of medium, containing glycine at the appropriate concentration, to freeze-dried radioactive glycine such that the radioactive concentration was $0 \cdot 5-1 \mu \mathrm{Ci} / \mu \mathrm{l}$. $\left[2-{ }^{3} \mathrm{H}\right] \mathrm{Glycine}$ at a specific activity of about $12 \mathrm{Ci} / \mathrm{mmol}$ and [U${ }^{14} \mathrm{C}$ glycine (sp. act. $110 \mathrm{mCi} / \mathrm{mmol}$ ) were supplied by Amersham (Aust) Strawberry Hills, New South Wales.

Unfertilized eggs were freed from the cumulus mass by incubation in medium containing 300 units hyaluronidase/ml (chromatographically purified from bovine testes: Sigma) and washed several times through $1 \mathrm{ml}$ medium.

$\mathrm{Na}^{+}$-depleted medium. Medium $\mathrm{M} 2$ was prepared depleted of $\mathrm{Na}^{+}$by replacing $\mathrm{NaCl}$ equimolarly with choline chloride ( 3 times crystallized; Sigma Product No. C7017) and $\mathrm{NaHCO}_{3}$ with $\mathrm{KHCO}_{3}$. Taking into account the $\mathrm{NaOH}$ used to bring the Hepes $(N$-2-hydroxyethyl piperazine- $N^{1}$-2-ethane sulphonic acid) to $\mathrm{pH} 7.4(\sim 8 \mathrm{~mm})$, this medium contained $32 \mathrm{~mm}-\mathrm{Na}^{+}$.

Uptake measurements. To measure glycine uptake, washed eggs or embryos were incubated in a 20-50 $\mu \mathrm{l}$ droplet of radioactive medium under $4 \mathrm{ml}$ Silcone 200 fluid $\left(50 \mathrm{~mm}^{2} \mathrm{~s}^{-1}\right.$; Dow Corning, Blacktown, New South Wales), at room temperature $\left(22^{\circ} \mathrm{C}\right)$, on ice $\left(2^{\circ} \mathrm{C}\right)$, in a water-jacketed incubator or on a heating block $\left(37^{\circ} \mathrm{C}\right)$.

After an appropriate time the eggs or embryos were removed from the droplet and rapidly washed 4 times in 1-2 $\mathrm{ml}$ of the same ice cold medium without glycine. Then, 1-10 embryos were placed in a plastic mini-counting vial to which was added $0.2 \mathrm{ml} \mathrm{H}_{2} \mathrm{O}$, before liquid scintillation analysis.

Efflux measurements. To measure efflux, eggs or embryos were allowed to accumulate $\left[{ }^{3} \mathrm{H}\right]$ glycine for the indicated times, washed twice as above in medium containing no glycine (total time, $2 \mathrm{~min}$ ) and then placed in fresh non-radioactive medium at the indicated glycine concentration. At various subsequent times, embryos were washed 4 times as above before liquid scintillation analysis.

Metabolic studies. After incubation for $120-200 \mathrm{~min}$ at 22 and $37^{\circ} \mathrm{C}$ in Medium M2 supplemented with $\left[\mathrm{U}-{ }^{14} \mathrm{C}\right] \mathrm{glycine}(2.5 \mu \mathrm{Ci} / \mu \mathrm{l})$ embryos were collected, washed, and stored with minimal carryover of medium at $-20^{\circ} \mathrm{C}$. The embryos were then frozen and thawed rapidly three times after addition of $10 \mu \mathrm{H} \mathrm{H}_{2} \mathrm{O}$, and then $10 \mu 125 \%(\mathrm{w} / \mathrm{v}) \mathrm{CCl}_{3} \mathrm{COOH}$ were added. After standing in ice for $30 \mathrm{~min}$ the acid-insoluble fraction was collected by centrifugation $(5000 \mathrm{~g} ; 5 \mathrm{~min})$, washed twice with $20 \mu \mathrm{l} \%$ (w/v) $\mathrm{CCl}_{3} \mathrm{COOH}$, and finally dissolved by heating overnight at $50^{\circ} \mathrm{C}$ in $50 \mu \mathrm{l}$ 
$1.0 \mathrm{M}-\mathrm{NaOH}$. Samples of this solution were neutralized with $\mathrm{HCl}$ and the radioactivity was determined. Acid-soluble supernatants were combined and samples subjected to chromatography. This technique yields $\sim 80 \%$ acid-soluble fraction (Schultz et al., 1981).

Paper chromatography. Portions of the acid-soluble supernatants prepared as above were analysed by descending paper chromatography on Whatman 3MM paper using the indicated solvents. Markers were run concurrently. Amino acids were located by staining with ninhydrin; pyruvate and lactate were located by comparison with radiolabelled standards run in adjacent lanes. After staining, chromatograms were dried, cut into $10 \mathrm{~mm}$ segments, and placed in vials with $0.2 \mathrm{ml} \mathrm{H}_{2} \mathrm{O}$; then radioactivity was determined.

Liquid scintillation analysis and standardization. All samples were counted in $3 \mathrm{ml}$ scintillation cocktail $(0 \cdot 7 \%$ diphenyloxazole, 0.07\% 1,4-bis[5-phenyl 2-oxazolyl]-benzene, 30\% Triton X-100 in toluene) using a Packard Tricarb 2660 Liquid Scintillation System or LKB 1217 Rack Beta Liquid Scintillation Counter at about $30 \%$ efficiency for ${ }^{3} \mathrm{H}$ and $80 \%$ for ${ }^{14} \mathrm{C}$ with backgrounds of 8 c.p.m. and 22 c.p.m. respectively. When necessary absolute efficiency of liquid scintillation counting was determined by internal standardization using ${ }^{3} \mathrm{H}_{2} \mathrm{O}$ and $\left[{ }^{14} \mathrm{C}\right]$ benzoic acid.

All uptake measurements were internally standardized as follows: at the end of an incubation three $2 \mu \mathrm{l}$ samples of radioactive medium were diluted with $\mathrm{H}_{2} \mathrm{O}$, and $0.2 \mathrm{ml}$ counted. The mean radioactivity from these samples was used to calculate the specific radioactivity of the droplet using the known glycine concentration and allowing for $\left[{ }^{3} \mathrm{H}\right]$ glycine contribution. Background samples consisted of appropriate volumes of the last wash medium and rarely differed from absolute background.

Statistics. Values presented are means \pm s.e.m. for 6-8 observations unless otherwise indicated. Statistical testing was by analysis of variance or Student's $t$ test. Kinetic parameters of glycine uptake were determined by two different linear transformations: the Lineweaver-Burk plot of the reciprocal of uptake rate as a function of the reciprocal of substrate concentration and the EadieHofstee plot of the uptake rate as a function of the ratio of uptake rate to substrate concentration. The latter has advantages in revealing the presence of multiple uptake mechanisms and is amenable to graphical resolution into component systems by the method of Rosenthal (1967).

\section{Results}

\section{Efflux and exchange}

As shown in Table 1 efflux of pre-accumulated $\left[{ }^{3} \mathrm{H}\right]$ glycine into amino acid-free medium at 22 or $37^{\circ} \mathrm{C}$ was insignificant at any of the embryonic stages examined over $10 \mathrm{~min}$. When the effects of temperature (Table 3 and below) are considered, these results confirm that the washing procedure carried out on ice with amino acid-free medium over a period of $5 \mathrm{~min}$ did not result in significant losses of embryonic $\left[{ }^{3} \mathrm{H}\right]$ glycine. However, significant efflux was observed from blastocysts during $30 \mathrm{~min}$ at 37 and $22^{\circ} \mathrm{C}(P<0.001)$.

When glycine was added to the incubation medium it was possible to examine exodus of preaccumulated $\left[{ }^{3} \mathrm{H}\right]$ glycine by exchange with external unlabelled glycine by measuring the decrease of embryonic $\left[{ }^{3} \mathrm{H}\right]$ glycine. Two-cell embryos and morulae showed very little exchange at 22 or $37^{\circ} \mathrm{C}$, but blastocysts did exhibit exchange at both temperatures. However, this exchange occurred at a rate approximately equal to efflux rate such that internal blastocyst $\left[{ }^{3} \mathrm{H}\right]$ glycine levels were reduced by a maximum of about $30 \%$ during incubation for $35 \mathrm{~min}$ at $37^{\circ} \mathrm{C}$ in medium containing $1 \mathrm{~mm}$ glycine. Analysis of variance of these results showed no significant difference when glycine was present in the external medium. Since uptake at all stages was linear for up to $2 \mathbf{h}$ (Text-fig. 1) the internal $K_{\mathrm{m}}$ for efflux must be high. Internal levels of glycine in 2-cell embryos reached 1.9 pmol, i.e. a total internal concentration of about $25 \mathrm{~mm}$, and similar levels were reached in the blastocyst, although efflux was only very low in blastocysts and absent in 2-cell embryos. 
Table 1. Efflux and exchange of $\left[{ }^{3} \mathrm{H}\right]$ glycine by preimplantation mouse embryos at 22 and $37^{\circ} \mathrm{C}^{*}$

\begin{tabular}{|c|c|c|c|c|c|c|}
\hline & \multirow[b]{2}{*}{${ }^{\circ} \mathrm{C}$} & \multirow{2}{*}{$\begin{array}{c}\text { Initial uptake } \\
\left(\text { fmol embryo }^{-1}\right)\end{array}$} & \multicolumn{2}{|c|}{ Efflux $(\%$ of initial) } & \multicolumn{2}{|c|}{ Exchange $(\%$ of initial) } \\
\hline & & & $10 \mathrm{~min}$ & $30 \mathrm{~min}$ & $15 \mathrm{~min}$ & $35 \mathrm{~min}$ \\
\hline 2-cell $(46 \mathrm{~h})$ & $\begin{array}{l}37 \\
22\end{array}$ & $\begin{array}{l}242 \pm 29 \\
667 \pm 20\end{array}$ & $\begin{array}{l}115 \pm 19 \\
110 \pm 17\end{array}$ & $\begin{array}{l}102 \pm 18 \\
106 \pm 12\end{array}$ & $\begin{array}{l}102 \pm 10 \\
107 \pm 12\end{array}$ & $\begin{array}{r}80 \pm 10 \\
103 \pm 5\end{array}$ \\
\hline Morula (72 h) & $\begin{array}{l}37 \\
22\end{array}$ & $\begin{array}{l}200 \pm 20 \\
334 \pm 20\end{array}$ & $\begin{array}{c}91 \pm 9 \\
109 \pm 17\end{array}$ & $\begin{array}{c}86 \pm 6 \\
109 \pm 18\end{array}$ & $\begin{array}{r}102 \pm 11 \\
99 \pm 15\end{array}$ & $\begin{array}{l}93 \pm 6 \\
98 \pm 16\end{array}$ \\
\hline Blastocyst (96 h) & $\begin{array}{l}37 \\
22\end{array}$ & $\begin{array}{l}331 \pm 36 \\
762 \pm 81\end{array}$ & $\begin{array}{r}109 \pm 15 \\
87 \pm 10\end{array}$ & $\begin{array}{l}73 \pm 5 \\
59 \pm 5\end{array}$ & $\begin{array}{r}81 \pm 11 \\
102 \pm 23\end{array}$ & $\begin{array}{l}74 \pm 12 \\
70 \pm 12\end{array}$ \\
\hline
\end{tabular}

* Embryos were incubated in medium containing $\left[{ }^{3} \mathrm{H}\right]$ glycine $(1 \mathrm{mM})$ for $20 \mathrm{~min}\left(\mathrm{M} 2,37^{\circ} \mathrm{C}\right)$ or $80 \mathrm{~min}\left(\mathrm{~PB} 1,22^{\circ} \mathrm{C}\right)$ then washed and placed in the same medium containing $1 \mathrm{mm-glycine} \mathrm{(exchange)} \mathrm{or} \mathrm{no} \mathrm{glycine} \mathrm{(efflux).} \mathrm{Values} \mathrm{at} 22^{\circ} \mathrm{C}$ are interpolations from values obtained at 10,20 and $40 \mathrm{~min}$. Efflux and exchange values are expressed as $\%$ of the initial uptake remaining after transfer to and incubation in non-radioactive media. Values are mean \pm s.e.m. of 7 observations at $37^{\circ} \mathrm{C}$ and 3 observations at $22^{\circ} \mathrm{C}$.

\section{Developmental pattern of uptake}

Embryos of all stages continued to take up $\left[{ }^{3} \mathrm{H}\right]$ glycine for $2 \mathrm{~h}$ at $37^{\circ} \mathrm{C}$ at a constant rate (Textfig. 1). Lines of best fit were fitted by least squares linear regression. The correlation coefficients were $>0.991$. The developmental pattern of uptake over $20 \mathrm{~min}$ in $140 \mu \mathrm{M}$ - and $1 \mathrm{mM}$-glycine at 22 and $37^{\circ} \mathrm{C}$ is shown in Text-fig. 2. At $1 \mathrm{~mm}$ the uptake by morulae was significantly less than that by 2-cell embryos at $22^{\circ} \mathrm{C}(n=10, P<0.01)$ but about the same as that by 2 -cell embryos at $37^{\circ} \mathrm{C}$. The blastocyst uptake was always greatest.

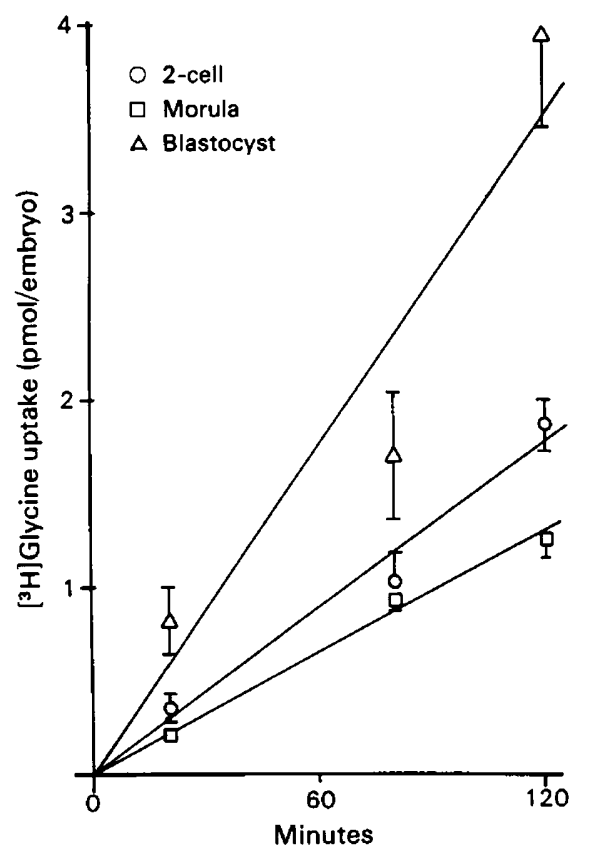

Text-fig. 1. Uptake of $\left[{ }^{3} \mathrm{H}\right]$ glycine $\left(37^{\circ} \mathrm{C}, 1 \mathrm{mM}\right)$ by 2 -cell, morula and blastocyst-stage mouse embryos. Lines of best fit were fitted by least squares linear regression. Values are mean \pm s.e.m. for 6 or 7 observations. 


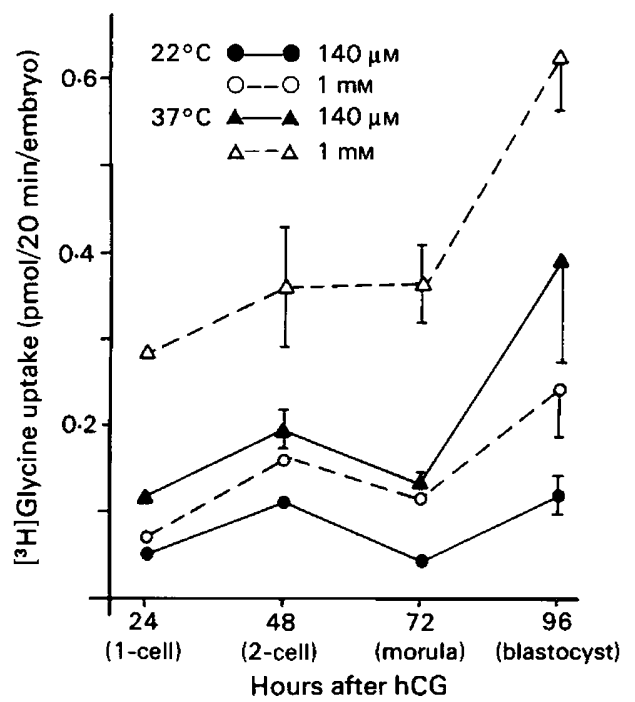

Text-fig. 2. Initial $\left[{ }^{3} \mathrm{H}\right]$ glycine uptake rate of preimplantation mouse embryos. Values are mean \pm s.e.m. for 3-8 observations. When absent the s.e.m. was less than area occupied by symbol.

\section{Saturation}

Uptake of $\left[{ }^{3} \mathrm{H}\right]$ glycine by 2-cell embryos was saturable at both $37^{\circ} \mathrm{C}$ (Text-fig. 3) and $22^{\circ} \mathrm{C}$ (results not shown). Linear transformation of these results by the Lineweaver-Burk method and fitting of a line of best fit by least squares linear regression (correlation coefficient $0.997,8$ glycine concentrations, $7 \cdot 4-1665 \mu \mathrm{M}$ ) showed $K_{\mathrm{m}}=89 \mu \mathrm{M}$ and $V_{\max }=15 \mathrm{fmol} \mathrm{min}^{-1}$ embryo $^{-1}$. The curve for blastocysts showed evidence of more than one uptake system (Text-fig. 3). Lineweaver-Burk

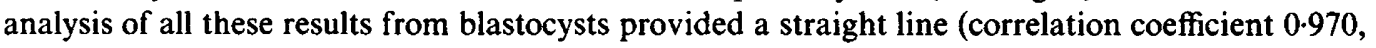
16 glycine concentrations $8-10000 \mu \mathrm{M}, 2$ experiments), showing $K_{\mathrm{m}}$ to be $144 \mu \mathrm{M}$ and $V_{\max }$ of 33 fmol $\min ^{-1}$ embryo ${ }^{-1}$. However, Eadie-Hofstee plots of these blastocyst data were curvilinear, a

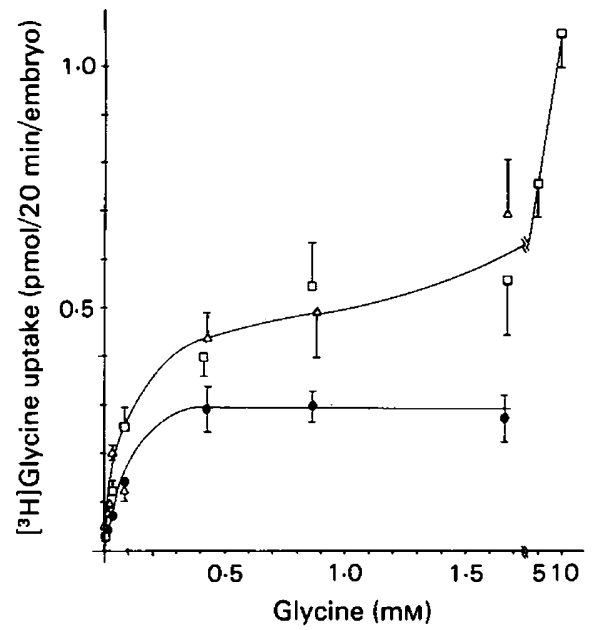

Text-fig. 3. Substrate dependence of $\left[{ }^{3} \mathrm{H}\right]$ glycine uptake rate in 2 -cell $(\odot)$ and blastocyst $(\triangle$, $\square)$ stage embryos. Two values for blastocysts represent two separate experiments. For each experiment, values are mean \pm s.e.m. for 6-8 observations. 
common finding in studies of animal cell amino acid transport (Reichberg \& Gelehrter, 1980). Attempts to resolve the Eadie-Hofstee curve graphically suggested the presence of at least two discrete systems, one with a very high affinity $\left(K_{\mathrm{m}} \sim 15 \mu \mathrm{M}\right)$ but low $V_{\max }\left(7 \mathrm{fmol} \mathrm{\textrm {min } ^ { - 1 }}\right.$ embryo $\left.^{-1}\right)$ and another with low affinity $\left(K_{\mathrm{m}} \sim 607 \mu \mathrm{M}\right)$ and high $V_{\max }\left(40 \mathrm{fmol} \mathrm{min}^{-1}\right.$ embryo $\left.^{-1}\right)$. However, this treatment did not take into account the $\mathrm{Na}^{+}$-independent uptake which may represent diffusion or some other system (Table 4), and so these values must be regarded as approximate.

\section{$\mathrm{Na}^{+}$requirement}

The rate of glycine $(140 \mu \mathrm{M})$ uptake in normal medium $\left(\mathrm{Na}^{+}=130 \mathrm{mM}\right)$ and $\mathrm{Na}^{+}$-depleted medium $\left(\mathrm{Na}^{+}=32 \mathrm{mM}\right)$ at $37^{\circ} \mathrm{C}$ was determined at different developmental stages and results are shown in Table 2. A more complete developmental pattern at $22^{\circ} \mathrm{C}$ is shown in Text-fig. 4 . In all cases uptake occurred in the lower $\mathrm{Na}^{+}$concentration, but the proportion of uptake which was dependent on high $\mathrm{Na}^{+}$levels was greatest in the blastocyst and least in one-cell embryos. $\mathrm{The}^{+\mathrm{Na}^{+}}$ independent uptake at $37^{\circ} \mathrm{C}$ appeared to be constant at all developmental stages.

Table 2. $\mathrm{Na}^{+}$dependence of glycine $(140 \mu \mathrm{M})$ uptake by preimplantation mouse embryos at $37^{\circ} \mathrm{C}$ (fmol $20 \mathrm{~min}^{-1}$ embryo- $^{-1}$ )

\begin{tabular}{lll}
\hline & \multicolumn{2}{c}{$\mathrm{Na}^{+}$} \\
\cline { 2 - 3 } \multicolumn{1}{c}{ Stage } & $130 \mathrm{mM}$ & $32 \mathrm{MM}$ \\
\hline Fertilized egg $(45 \mathrm{~h})$ & $115 \pm 11$ & $45 \pm 2$ \\
Morula $(70 \mathrm{~h})$ & $156 \pm 6$ & $55 \pm 7$ \\
Blastocyst $(96 \mathrm{~h})$ & $395 \pm 120$ & $51 \pm 11$ \\
\hline
\end{tabular}

Values are mean \pm s.e.m. for 6 or 7 observations.

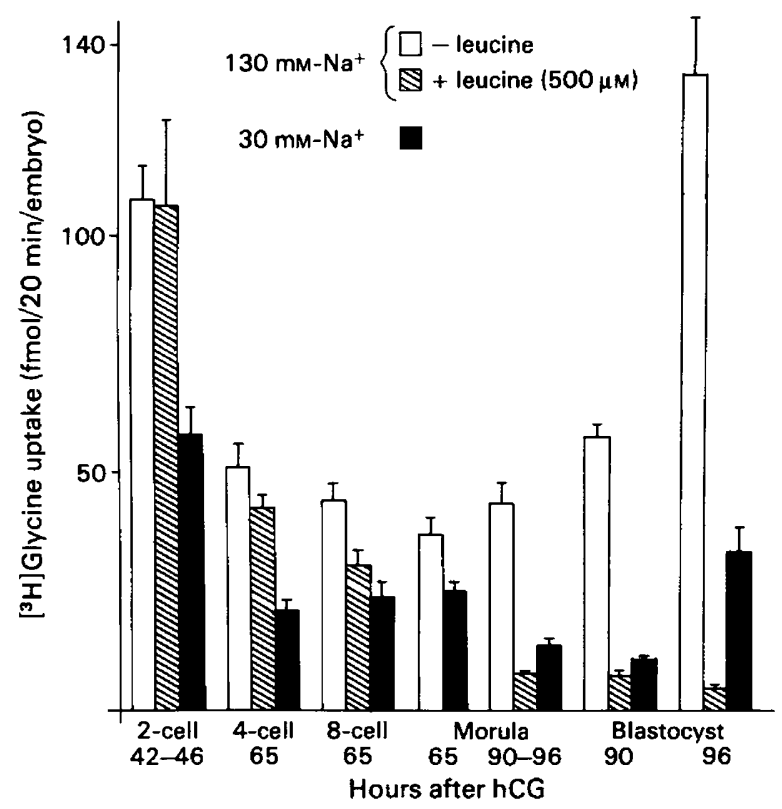

Text-fig. 4. Sodium ion dependence of and leucine competition for $\left[{ }^{3} \mathrm{H}\right]$ glycine $(140 \mu \mathrm{M})$ uptake in mouse embryos at $22^{\circ} \mathrm{C}$. Values are mean \pm s.e.m. for 3-6 observations. 


\section{Temperature dependence}

Glycine (1 mM) uptake by embryos of all stages was reduced to the same insignificant level at $2^{\circ} \mathrm{C}$ (Table 3) but increased about 3-fold from 22 to $37^{\circ} \mathrm{C}$ for eggs, morulae and blastocysts. The apparent Arrhenius activation energy calculated from these results at $1 \mathrm{mM}$-glycine is $89 \pm 6(n=$ 3) $\mathrm{kJ} \mathrm{mol}^{-1}$ with no significant variation during development from egg to blastocyst. This value is based on the assumption that uptake rate for blastocysts at $1 \mathrm{~mm}$ is a maximum. The results above would indicate that this is not precisely so. However, using the calculated combined $V_{\max }(33 \mathrm{fmol}$ $\min ^{-1}$ embryo $^{-1}$ ) based on two uptake systems does not significantly alter the calculated activation energy.

Table 3. Effect of temperature on $\left[{ }^{3} \mathrm{H}\right] \mathrm{glycine}$ uptake by mouse eggs/embryos (fmol 20 min $^{-1}$ embryo $^{-1}$ )

\begin{tabular}{lcccc}
\hline \multicolumn{1}{c}{ Stage } & Glycine & $2^{\circ} \mathrm{C}$ & $22^{\circ} \mathrm{C}$ & $37^{\circ} \mathrm{C}$ \\
\hline Unfertilized egg $(24 \mathrm{~h})$ & $1 \mathrm{mM}$ & $4 \pm 2$ & $93 \pm 5$ & $284 \pm 8$ \\
& $140 \mu \mathrm{M}$ & $5 \pm 2$ & $47 \pm 3$ & $115 \pm 1$ \\
2-cell $(46 \mathrm{~h})$ & $1 \mathrm{mM}$ & $3 \pm 1$ & $161 \pm 10$ & $361 \pm 9$ \\
Morula $(72 \mathrm{~h})$ & $140 \mu \mathrm{M}$ & $6 \pm 3$ & $43 \pm 4$ & $133 \pm 12$ \\
Blastocyst $(96 \mathrm{~h})$ & $1 \mathrm{mM}$ & $8 \pm 3$ & $203 \pm 36$ & $652 \pm 18$ \\
& $140 \mu \mathrm{M}$ & $8 \pm 3$ & $107 \pm 26$ & $395 \pm 120$ \\
\hline
\end{tabular}

Values are mean \pm s.e.m. for $6-12$ observations.

\section{Competition}

Competition by a number of amino acids at $500 \mu \mathrm{M}$ for glycine $(140 \mu \mathrm{M})$ uptake was measured at several stages of development at $37^{\circ} \mathrm{C}$ (Table 4) and $22^{\circ} \mathrm{C}$ (Text-fig. 4). Leucine has a strong reactivity with systems $L$ and $A$. Significant competition by leucine for glycine uptake did not occur until the morula stage $\left(90 \mathrm{~h}\right.$ after hCG) at 37 or $22^{\circ} \mathrm{C}$. Thereafter, leucine competition reduced glycine uptake to $5-10 \%$ of control values. Alanine, which reacts strongly with the A-system, showed a similar pattern of response. Methyl amino isobutyric acid (MeAIB) is reported to be an Asystem specific amino acid (Christensen, 1979). We could find no consistent inhibition by MeAIB.

Table 4. Competition for glycine uptake by preimplantation mouse embryos (fmol 20 $\min ^{-1}$ embryo $\left.{ }^{-1}\right)^{*}$

\begin{tabular}{lcccc}
\hline & & \multicolumn{3}{c}{ Competing amino acid } \\
\cline { 3 - 5 } & Control & Leucine & Alanine & MeAIB \\
\hline Fertilized egg (45 h) & $115 \pm 11$ & $97 \pm 4$ & $146 \pm 11$ & $116 \pm 9$ \\
Morula $(70 \mathrm{~h})$ & $156 \pm 6$ & $135 \pm 7$ & $122 \pm 20$ & $112 \pm 8$ \\
Blastocyst $(96 \mathrm{~h})$ & $358 \pm 88$ & $33 \pm 7$ & $61 \pm 9$ & $531 \pm 121$ \\
& $147 \pm 24 \dagger$ & $5 \pm 1 \dagger$ & $15 \pm 2 \dagger$ & $170 \pm 15 \dagger$ \\
\hline
\end{tabular}

* Embryos were incubated in $140 \mu \mathrm{M}-\left[{ }^{3} \mathrm{H}\right]$ glycine with or without the competing amino acid (500 $\mu \mathrm{M})$ for $20 \mathrm{~min}$ at $37^{\circ} \mathrm{C}$. Values are mean \pm s.e.m. for $6-8$ observations.

$\dagger$ This experiment was at $22^{\circ} \mathrm{C}$.

\section{Metabolism}

Since pre-accumulated glycine did not efflux from the early embryos it was important to determine any metabolic conversion which might occur to prevent efflux. Morulae and blastocysts were incubated in medium containing $\left[{ }^{14} \mathrm{C}\right]$ glycine at 22 and $37^{\circ} \mathrm{C}$ for $200 \mathrm{~min}$. The incorporation 
of glycine into the acid-insoluble fraction represented $10 \pm 1 \%$ of total uptake for blastocysts at $22^{\circ} \mathrm{C}$ and $23 \pm 6 \%$ at $37^{\circ} \mathrm{C}$. Analysis of the acid-soluble fraction by paper chromatography (Textfig. 5) revealed that, after $120 \mathrm{~min}$ at $37^{\circ} \mathrm{C}$, about half of the acid-soluble ${ }^{14} \mathrm{C}$ appeared as glycine, $17 \%$ as alanine, $5 \%$ as serine and the rest was unidentified but did not appear as lactate or pyruvate.

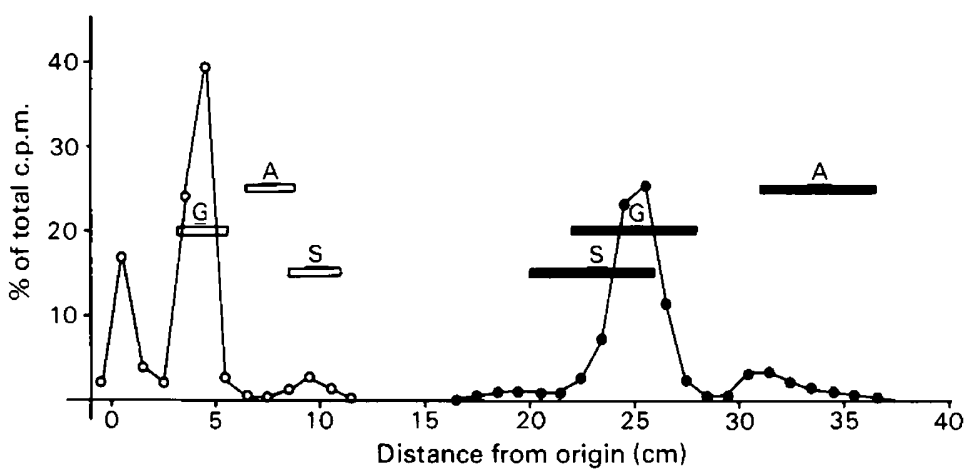

Text-fig. 5. Chromatographic analysis of ${ }^{14} \mathrm{C}$ accumulated as $\left[{ }^{14} \mathrm{C}\right]$ glycine by blastocysts. Solvents: $O, t$-butanol :methylethylketone: $\mathrm{NH}_{3}: \mathrm{H}_{2} \mathrm{O}(5: 3: 1: 1$ by vol. $)$; $O$, butan-1ol :acetone : acetic acid: $\mathrm{H}_{2} \mathrm{O}(7: 7: 2: 4$ by vol.). Bars indicate location of $1 \mu \mathrm{mol}$ glycine $(\mathrm{G})$, serine (S) and alanine (A) stained by ninhydrin dipping.

\section{Discussion}

Our results show that glycine uptake in preimplantation embryos is concentrative, saturable, temperature-dependent and requires sodium ions. These are all characteristics of mediated transport. We therefore conclude that glycine enters mouse embryos by mediated systems similar to those previously reported for methionine (Borland \& Tasca, 1974; Kaye et al., 1982) and alanine uptake (DiZio \& Tasca, 1977).

The increase in uptake rate after the morula stage, which is associated with the appearance of efflux, complex kinetics, susceptibility to competition from alanine and leucine and an increased requirement for sodium ion, suggests the activation of an additional transport system for glycine at this time. These features and the high external $K_{\mathrm{m}}$ indicate that this later system is the previously reported A-like system (Kaye et al., 1982). In particular the inhibition by alanine (a model substrate for A systems) strongly supports this conclusion, especially when the acknowledged high reactivity of glycine with A-like systems is considered. It follows that most of the glycine uptake in blastocysts is linked to $\mathrm{Na}^{+}-\mathrm{K}^{+}$-ATPases in a transepithelial transport system as described for alanine (DiZio \& Tasca, 1977). Since oviducal fluid contains high levels of glycine (Wales, 1973) this would favour uptake by the low affinity A-like system.

The mechanism of glycine uptake in the pre-compaction embryo differs markedly from the Alike and L-like systems. It has a high affinity $\left(K_{\mathrm{m}} 84 \mu \mathrm{M}\right)$, is inhibited by leucine only to a small extent, is very weakly exchangeable and requires sodium ions for maximum activity. These features are not those of the L-like system proposed for pre-compaction methionine uptake, which is not inhibited by glycine (Borland \& Tasca, 1974; Holmberg \& Johnson, 1979). They are features of the glycine-specific mechanism described for several other preparations (Eavenson \& Christensen, 1967; Kilberg, 1982).

The very weak exchange component of glycine uptake demonstrated primarily by the direct relationship between uptake rate and time, and supported by the efflux studies (Table 1), is unusual for amino acid transport systems but has been observed previously for glycine uptake by pigeon erythrocytes (Eavenson \& Christensen, 1967). Total internal glycine levels achieved by 2-cell 
embryos reached $\sim 25 \mathrm{~mm}$ (Text fig. 2; Schultz et al., 1981). Eavenson \& Christensen (1967) suggested that the strongly concentrative $g l y$-system and the consequently high glycine concentration gradient it produces might serve as an energy generator for the production of gradients of other endogenous amino acids. Thus the decrease in glycine pool during cleavage development (Schultz et al., 1981) might be used to accumulate the other neutral amino acids.

The activation energy of $89 \mathrm{~kJ} \mathrm{~mol}^{-1}$ agrees closely with the value obtained for glycine uptake in the pigeon erythrocyte and is further evidence of a carrier-mediated mechanism (Eavenson \& Christensen, 1967). We could find no significant differences between the activation energies at various stages of preimplantation development despite the appearance of the second transport system. This might be due to the very low affinity of this second system for glycine and thus our uptake experiments carried out at $1 \mathrm{~mm}$ concentration may not accurately reflect $V_{\max }$ for this second system.

In confirmation of previous results (Kaye et al., 1982) we could not demonstrate appreciable inhibition by MeAIB of glycine uptake by the A-like system of the blastocyst but we still believe this system to have greater resemblance to system A than system ASC. It would appear that MeAIB is not a model substrate for mouse blastocyst A-like systems. Similar conclusions have been reached for transport of glycine by the A-system in hepatoma cells in culture (Christensen \& Handlogten, 1981).

We have examined the effects of peptide hormones on glycine transport and found that uptake is stimulated in blastocysts but not 2-cell embryos (Kaye, 1983). This resistance to peptide hormone activation is typical of the $g l y$-system. Hormonal activation of amino acid transport usually affects A-like systems only. We take this as further evidence that glycine uptake in the early embryo occurs by a glycine-specific system (at least) and that this system is supplemented at about the time of compaction by the A-like sytem previously described. Christensen (1973) has suggested that the Asystem may be a differentiative variant of the $g l y$-system. The $g l y$-system precedes the appearance of the A-system in the mouse embryo and suggests a differentiative adaptation which might be associated with fluid accumulation in the blastocyst and/or the opportunity for regulation of transport activity via hormonal or adaptive regulation.

The metabolic fate of accumulated glycine is interesting. When acid-soluble $\left[{ }^{14} \mathrm{C}\right]$ glycine accumulated by blastocysts was analysed by paper chromatography, most of the ${ }^{14} \mathrm{C}$ was associated with glycine even after $2 \mathrm{~h}$. The remainder had been converted to serine and possibly alanine or was unidentified. Since alanine and possibly serine can compete for uptake and both exchange for external glycine in erythrocytes (Eavenson \& Christensen, 1967) it seems likely that they would also exchange for glycine taken up by mouse embryos and therefore these internal compartments must be only weakly exchangeable.

The appearance of label in serine and alanine suggests that glycine is being converted to serine probably by the action of serine hydroxymethyltransferase. Alanine could arise by transamination of pyruvate formed from glycine. This conclusion is supported by results of a preliminary experiment in which about $30 \%$ of acid-soluble ${ }^{3} \mathrm{H}$ accumulated as $\left[{ }^{3} \mathrm{H}\right]$ glycine by blastocysts over $20 \mathrm{~min}$ showed chromatographically as serine. Furthermore, Quinn \& Wales (1973) observed synthesis of a number of amino acids, including alanine, from pyruvate. The absence of labelled pyruvate in our studies is not surprising since its intracellular pool is believed to be small (Wales, 1975). Glycine is a key metabolite in most tissues. The principal pathway by which glycine is catabolized is the glycine cleavage system, a reversible enzyme complex which in combination with serine hydroxymethyltransferase catalyses the conversion of 2 molecules of glycine to one molecule each of serine, ammonia and $\mathrm{CO}_{2}$ (see Kikuchi, 1973, for review). In this sequence the $\mathrm{CO}_{2}$ arises from the carboxylcarbon of glycine. Thus glycine may be converted to $\mathrm{CO}_{2}$ by this cleavage system or by the oxidation of pyruvate produced by the action of serine pyruvate transaminase on serine arising from glycine via serine hydroxymethyltransferase. This latter pathway would involve glycine in energy metabolism (in addition to macromolecular synthesis) as well as the provision of reducing equivalents and one carbon fragments. At $37^{\circ} \mathrm{C}, 23 \%$ of the glycine taken up by 
blastocysts appeared as acid-insoluble material, probably protein, but because of glycine's central role in nucleotide metabolism possibly also as nucleic acids. This acid-insoluble fraction of incorporation is about the same as that observed for other amino acids (Epstein \& Smith, 1973; Borland \& Tasca, 1974; Kaye et al., 1982).

In conclusion our results show the presence in pre-compaction mouse embryos of the $g l y$-system for amino-acid uptake. This system is not subject to efflux and is concentrative. Glycine uptake becomes complex after compaction with the participation of the additional A-like system. This system is also concentrative for glycine. Analysis of the metabolic fate of glycine reveals conversion to serine and alanine and suggests that the disappearance of the embryonic glycine pool (Schultz et al., 1981) may be due to conversion to $\mathrm{CO}_{2}$ and energy as well as other macromolecules.

We thank Kevin Spring for technical assistance, Dr Len Martin for helpful discussion and the office staff of the Department for word processing the manuscript. This research was supported by grants from NHMRC of Australia and University of Queensland Special Research Fund.

\section{References}

Borland, R.M. \& Tasca, R.J. (1974) Activation of a $\mathrm{Na}^{+}$. dependent amino acid transport system in preimplantation mouse embryos. Devl Biol. 30, 169-182.

Brinster, R.L. (1965) Studies on the development of mouse embryos in vitro. IV Interaction of energy sources. J. Reprod. Fert. 10, 227-240.

Caro, C.M., Trounson, A.O. \& Pugh, P.A. (1982) Mouse embryo development in vitro is affected by protein type and its concentration. Proc. Aust. Soc. Reprod. Biol. 14, 112, Abstr.

Christensen, H.N. (1973) On the development of amino acid transport systems. Fedn Proc. Fedn Am. Socs exp. Biol. 32, 19-28.

Christensen, H.N. (1979) Exploiting amino acid structure to learn about membrane transport. Adv. Enzymol. 49, 41-101

Christensen, H.N. \& Handlogten, M.E. (1981) Role of system $G l y$ in glycine transport in monolayer cultures of liver cells. Biochem. Biophys. Res. Commun. 98, 102-107.

DiZio, S.M. \& Tasca, R.J. (1977) Sodium dependent amino acid transport in preimplantation mouse embryos. Devl Biol. 59, 198-205.

Dulbecco, R. \& Vogt, M. (1954) Plaque formation and isolation of pure lines with poliomyelitis viruses. $J$. exp. Med. 99, 167-182.

Eavenson, E. \& Christensen, H.N. (1967) Transport systems for neutral amino acids in the pigeon erythrocyte. J. biol. Chem. 242, 5386-5396.

Epstein, C.J. \& Smith, S.A. (1973) Amino acid uptakes and protein synthesis in preimplantation mouse embryos. Devl Biol. 33, 171-184.

Fulton, B.P. \& Whittingham, D.G. (1978) Activation of mammalian oocytes by intracellular injection of calcium. Nature, Lond. 273, 149-151.

Fry, B.J. \& Gross, P.R. (1970) Patterns and rates of protein synthesis in sea urchin embryos. I. Uptake and incorporation of amino acids during the first cleavage cycle. Devl Biol. 21, 105-124.
Holmberg, S.R.M. \& Johnson, M.H. (1979) Amino acid transport in the unfertilized and fertilized mouse egg. J. Reprod. Fert. 56, 223-231.

Kaye, P.L. (1983) Glycine transport in mouse embryos. Proc. Aust. Biochem. Soc. 15, 36, Abstr.

Kaye, P.L., Schultz, G.A., Johnson, M.H., Pratt, H.P.M. \& Church, R.B. (1982) Amino acid transport and exchange in preimplantation mouse embryos. $J$. Reprod. Fert. 65, 367-380.

Kikuchi, G. (1973) The glycine cleavage system : composition, reaction mechanism, and physiological significance. Molec. cell. Biochem. 1, 169-187.

Kilberg, M.S. (1982) Amino acid transport in isolated rat hepatocytes. J. Membrane Biol. 69, 1-12.

Quinn, P. \& Wales, R.G. (1973) Uptake and metabolism of pyruvate and lactate during preimplantation development of the mouse embryo in vitro. J. Reprod. Fert. 35, 273-287.

Reichberg, S.B. \& Gelehrter, T.D. (1980) Glucocorticoid inhibition of two discrete glycine transport systems in rat hepatoma cells. J. biol. Chem. 255, 5708-5714.

Rosenthal, H.E. (1967) A graphic method for the determination and presentation of binding parameters in a complex system. Analyt. Biochem. 20, $525-532$.

Schultz, G.A., Kaye, P.L., McKay, D.J. \& Johnson, M.H. (1981) Endogenous amino acid pool sizes in mouse eggs and preimplantation embryos. J. Reprod. Fert. 61, 387-393.

Sellens, M.H., Stein, S. \& Sherman, M.I. (1981) Protein and free amino acid content in preimplantation mouse embryos and in blastocysts under various culture conditions. J. Reprod. Fert. 61, 307-315.

Wales, R.G. (1973) The uterus of the ewe. II. Chemical analysis of uterine fluid collected by cannulation. Aust. J. biol. Sci. 26, 947-959.

Wales, R.G. (1975) Maturation of the mammalian embryo: biochemical aspects. Biol. Reprod. 12, 6681. 